\title{
STRATEGI OPTIMALISASI PERDAGANGAN LINTAS BATAS INDONESIA- MALAYSIA UNTUK MENINGKATAN KESEJAHTERAAN MASYARAKAT PULAU SEBATIK KABUPATEN NUNUKAN
}

\author{
Mahendra Putra Kurnia, \\ Fakultas Hukum Universitas Mulawarman, Jl.Sambaliung Kampus Gunung Kelua Samarinda, E- \\ mail: mp_sheva@yahoo.com
}

\begin{abstract}
ABSTRAKSI
Mewujudkan masyarakat yang sejahtera adalah tanggung jawab dari setiap negara, tak terkecuali bagi Pemerintah Republik Indonesia terhadap seluruh warga negaranya, terutama yang berdiam di kawasan perbatasan. Pulau Sebatik Kabupaten Nunukan adalah salah satu kawasan yang berbatasan dengan Kota Tawau, Malaysia. Dalam rangka mewujudkan kesejahteraan masyarakat Sebatik yang sejahtera diperlukan strategi optimalisasi perdagangan lintas batas yang berorientasi pada kesejahteraan dan kesetaraan.
\end{abstract}

Kata kunci : perdagangan lintas batas dan kesejahteraan

\section{PENDAHULUAN}

Perdagangan lintas batas antara Indonesia dengan Malaysia sebenarnya bukan hal baru, perundingan dan kesepakatan bilateral menyangkut perdagangan lintas batas telah dilakukan sejak tahun 1967. Diawali dengan joint communiqué (komunike bersama) antara delegasi Indonesia dan delegasi Malaysia mengenai pembicaraan masalah perdagangan dan ekonomi antara kedua negara tanggal 4 - 11 Mei 1967 yang diikuti dengan penandatangan kesepakatan dan pengaturan dasar perdagangan dan hubungan ekonomi antara kedua negara. Kesepakatan tersebut berlanjut dengan ditandatanganinya Agreement On Border Trade Between the Government of the Republic of Indonesia and the Government of the Malaysia (Persetujuan mengenai Perdagangan Lintas Batas antara Pemerintah Republik Indonesia dan Pemerintah Malaysia) di Jakarta pada tanggal 24 Agustus 1970. Tidak cukup sampai disini saja, kesepakatan perdagangan lintas batas negara Indonesia-Malaysia dilengkapi dengan Agreement on Travel Facilities for Sea Border Trade between Republic Indonesia and Malaysia (Perjanjian Mengenai Fasilitas Perjalanan Untuk Perdagangan Lintas Batas Antara Republik Indonesia dan Malaysia) yang ditandatangani di Jakarta pada tanggal 16 Oktober 1973 dan diratifikasi melalui Keppres No.34 tahun 1974 tanggal 6 Juli 1974/ LN No.36.

Sebagai tindak lanjut dari berbagai kesepakatan perdagangan lintas batas di atas, dibentuk General Border Committee (GBC) yang dalam struktur organisasinya terdapat Kelompok Kerja Sosial-Ekonomi Malaysia-Indonesia (KK Sosek Malindo) .Kelompok

Kerja Sosek Indonesia terdiri dari dua tingkat yaitu tingkat pusat dan daerah. KK Sosek Malindo tingkat pusat berkedudukan di Staf Teritorial TNI (Ster TNI) yang diketuai oleh Asisten Teritorial Kasum TNI (Aster Kasum TNI). Sedangkan KK Sosek Malindo tingkat daerah Kalimantan Barat berkedudukan di Badan Perencanaan Pembangunan Daerah (Bappeda) Propinsi Kalimantan Barat. Ketua Sosek Malindo tingkat daerah Kalimantan Timur adalah Kepala Bappeda Propinsi Kalimantan Timur. KK Sosek Malindo tingkat Daerah juga terdapat untuk daerah Johor-Malaka-Riau. Kelompok Kerja Sosek Malindo 
merupakan staf tingkat pusat yang bertanggung jawab kepada GBC melalui Staff Planning Committee (SPC). Sedangkan Kelompok Kerja Sosek Malindo tingkat daerah kedudukannya adalah sebagai pembantu KK Sosek Malindo tingkat pusat dengan tugas pokok mengkaji secara detil kerjasama sosial ekonomi di daerah/negeri dan memantau pelaksanaannya sesuai dengan arahan KK Sosek Malindo tingkat pusat. Untuk kelancaran tugas pokoknya, KK Sosek Malindo tingkat daerah dapat membentuk Kelompok Kerja Teknis (Tim Teknis). ${ }^{1}$

Melihat berbagai kesepakatan perdagangan lintas batas antara Indonesia-Malaysia berikut aspek kelembagaan yang menyertainya ditambah dengan lamanya jangka waktu yang dimiliki sejak kesepakatan ditandatangani, sudah sepantasnya jika aktivitas perdagangan lintas batas Indonesia-Malaysia membuat kondisi perekonomian di kawasan perbatasan Indonesia dalam kondisi yang maju, makmur, dan sejahtera. Namun perkembangan terkini justru cenderung kontradiktif dengan kondisi ideal. Fakta penelitian menunjukkan bahwa kondisi perekonomian kawasan perbatasan Indonesia secara keseluruhan maupun per-kawasan dalam kondisi yang terbelakang, terisolir, memiliki ketergantungan ekonomi dengan negara tetangga, aspek kelembagaan yang kurang terkoordinasi dengan baik, dan beberapa permasalahan terkait sarana-prasarana perdagangan lintas batas. ${ }^{2}$

Secara geografis, Pulau Sebatik Kabupaten Nunukan Provinsi Kalimantan Utara merupakan salah satu kawasan yang berada pada garis perbatasan. Desa Sungai Nyamuk dan Tanjung Aru Pulau Sebatik berbatasan langsung dengan Kota Tawau, Negeri Sabah, Malaysia. Perdagangan lintas batas antara Pulau Sebatik dengan Tawau sudah berlangsung sejak puluhan tahun yang lalu. Jenis barang yang diperdagangkan juga sangat beragam, mulai dari kebutuhan pokok sampai bahan bangunan. Penelitian yang dilakukan oleh Adri Patton menunjukkan bahwa adanya implikasi positif dari perdagangan lintas batas yang dilakukan selama ini, yaitu: (a) implikasi positif terkait dengan adanya kemampuan masyarakat untuk memenuhi kebutuhan dasar (pokok) dengan cara yang relatif lebih mudah dengan biaya yang relatif lebih murah dan waktu yang lebih cepat dibanding bila mereka harus membeli ke Ibu kota Kabupaten Nunukan; (b) meningkatnya usaha ekonomi masyarakat, dengan adanya aktifitas perdagangan lintas batas dapat mendorong masyarakat untuk mengembangkan usaha guna

\footnotetext{
${ }^{1}$ Disarikan dari Pusat Kajian Administrasi Internasional, 2004, “Laporan Akhir Kajian Manajemen Wilayah Perbatasan Negara", Lembaga Administrasi Negara, Jakarta, hlm.73-74. Secara rinci, tugas dan tanggung jawab KK Sosek Malindo dapat dilihat di halaman 74-77. Dokumen diunduh dari situs pencarian www.google.com pada hari Kamis 22 Juli 2011 Jam 23.00 WITA.

2 Antara lain lihat hasil penelitian: Adri Patton (Deskripsi Perdagangan Lintas Batas Antar Negara Indonesia dan Malaysia di Kecamatan Sebatik Kabupaten Nunukan, 2009), Mahendra Putra Kurnia (Harmonisasi Hukum Pengembangan Kawasan Perbatasan NKRI Berbasis Teknologi Geospasial, 2011), Ikhwanuddin Mawardi (Strategi Pengembangan Pusat Kegiatan Strategis Nasional di Kawasan Perbatasan Darat Sebagai Pintu Gerbang Aktivitas Ekonomi dan Perdagangan Dengan Negara Tetangga, 2010), dan artikel media Kompas (Nasionalisme di Tapal Batas, 10-20 Agustus 2009).
} 
meningkatkan penghasilan misalnya dengan membuka perkebunan rakyat, kerajinan tangan (home industry), dan lain-lain. ${ }^{3}$

Akan tetapi, kegiatan perdagangan lintas batas yang dilakukan selama ini juga menimbulkan implikasi negatif yaitu berupa terjadinya perdagangan lintas batas illegal yang sangat merugikan negara. Perdagangan illegal yang dimaksud disini adalah sering terjadinya penyelundupan barang-barang dari dan ke Tawau. Penyelundupan barangbarang tersebut bukan hanya barang-barang untuk kebutuhan pokok saja, tetapi juga penyelundupan barang-barang berbahaya seperti narkotika dan zat-zat terlarang. ${ }^{4}$

Berdasar dari uraian singkat di atas, tampak sangat penting untuk dilakukan kajian mendalam mengenai keberadaan perdagangan lintas batas di Pulau Sebatik Kabupaten Nunukan. Kajian ini dimaksudkan untuk mengidentifikasi faktor-faktor yang menjadi kekuatan, kelemahan, kesempatan dan ancaman (teknik analisa SWOT) 5 dari kegiatan perdagangan lintas batas di Pulau Sebatik Kabupaten Nunukan. Hasil dari kajian ini diharapkan dapat memberikan gambaran yang komprehensif mengenai kegiatan perdagangan lintas batas di Pulau Sebatik Kabupaten Nunukan untuk kemudian ditentukan strategi optimalisasi dari kegiatan perdagangan lintas batas tersebut.

\section{PERDAGANGAN LINTAS BATAS}

"Apa sebenarnya makna dari perdagangan lintas batas?". Jawaban dari pertanyaan tersebut menjadi pembahasan dalam sub-bab ini. Pada dasarnya sulit untuk menemukan literatur yang secara eksplisit menuliskan makna dari perdagangan lintas batas. Akan tetapi, makna perdagangan lintas batas dapat ditemukan jika merujuk pada definisi "bisnis internasional". Bisnis internasional adalah kegiatan komersial (commercial activity) lintas batas negara, yang dilakukan antar individu atau perusahaan yang berkewarganegaaran berbeda, berdasarkan prediksi-prediksi tertentu (future outcome), dan bertujuan untuk memperoleh keuntungan tertentu (engage in for gain). ${ }^{6}$

Dari definisi di atas sudah bisa ditafsirkan bahwa perdagangan lintas batas memiliki makna yang sama dengan bisnis internasional. Bahkan juga memiliki kesamaan makna jika disandingkan dengan frase "perdagangan internasional" atau "perniagaan internasional". Perbedaannya hanya pada penyebutannya. Pada akhirnya, dapat ditarik

\footnotetext{
${ }^{3}$ Adri Patton, 2009, "Deskripsi Perdagangan Lintas Batas Antar Negara Indonesia dan Malaysia di Kecamatan Sebatik Kabupaten Nunukan", hasil penelitian yang disampaikan dalam Diklat PIM II di Surabaya, hlm. 72-73.

4 Ibid., hlm.73.

5 Akronim dari SWOT adalah kekuatan (strengths), kelemahan (weaknesses), peluang (opportunities), dan ancaman (threats). Glaister and Falshaw menyatakan bahwa teknik analisa SWOT adalah teknik yang popular digunakan dalam perencanaan strategis (Iwan Vanany, 2011, "Pengadopsian Teknologi RFID: Analisa SWOT" dalam Jurnal Manajemen Usahawan Indonesia Vol.40 No.3 Mei-Juni 2011, hlm.271.

Berdasarkan penjelasan singkat mengenai Teknik Analisa SWOT tersebut, tepat kiranya jika metode ini digunakan untuk menentukan strategi optimalisasi perdagangan lintas batas di Kecamatan Sebatik Kabupaten Nunukan.

${ }^{6}$ Ida Bagus Wyasa Putra, 2000, Aspek-aspek Hukum Perdata Internasional dalam Transaksi Bisnis Internasional, Refika Aditama, Bandung, hlm.2.
} 
kesimpulan bahwa perdagangan lintas batas memiliki makna yang sama dengan bisnis internasional, perdagangan internasional, atau perniagaan internasional.

\section{FAKTOR-FAKTOR YANG MELATARBELAKANGI TERJADINYA PERDAGANGAN LINTAS BATAS DI PULAU SEBATIK KABUPATEN NUNUKAN}

Sebagaimana fenomena sosial pada umumnya, baik masyarakat tradisional maupun masyarakat modern tidak lagi hanya mempunyai misi untuk sekedar bertahan hidup, akan tetapi semuanya akan selalu berusaha untuk memenuhi kebutuhan baik yang bersifat kebutuhan dasar (fisik) dan kebutuhan lanjutan (sekunder dan tersier). Adapun kebutuhan yang menjadi prioritas pada setiap individu maupun setiap kelompok sangat bervariasi dan hal ini dipengaruhi oleh berbagai faktor, antara lain tingkat ekonomi, tingkat pendidikan, usia, jenis pekerjaan, lingkungan dan lain sebagainya.

Bagi masyarakat yang tinggal di daerah perbatasan, khususnya di Pulau Sebatik yang berbatasan langsung dengan Malaysia (Kota Tawau) sampai saat ini masih dihadapkan pada tuntutan pemenuhan kebutuhan dasar atau kebutuhan fisik semata. Hal ini disebabkan karena kebutuhan dasar tersebut sampai saat ini masih menjadi problem atau dengan kata lain belum dapat terpenuhi dengan baik. Kondisi masih sulitnya pemenuhan kebutuhan dasar tersebut sejak dahulu hingga kini masih dihadapi oleh masyarakat daerah perbatasan pada umumnya termasuk di Pulau Sebatik Kabupaten Nunukan.

Kondisi geografis Pulau Sebatik yang relatif lebih dekat dengan Kota Tawau, dibandingkan dengan wilayah lain yang berada di bawah kedaulatan NKRI, merupakan alasan utama terjadinya perdagangan lintas batas bagi kedua negara. Secara rinci faktorfaktor yang mempengaruhi terjadinya perdagangan lintas batas tersebut antara lain: faktor kondisi geografis dan topografis, aksesibilitas, dan adanya hubungan historis, kultural dan emosional antara penduduk Pulau Sebatik dengan penduduk Kota Tawau.

1. Faktor Geografis dan Topografis

Letak geografis dan topografis Pulau Sebatik yang berbatasan langsung dengan Kota Tawau merupakan salah satu faktor penyebab terjadinya perdagangan lintas batas di daerah ini. Kedekatan ini membuat biaya transportasi dan komunikasi menjadi lebih murah dan terjangkau.

2. Faktor Aksesibilitas

Akses transportasi sangat mudah, hal ini dikarenakan tersedianya aksesibilitas yang memadai (speed boat dan kapal) yang setiap harinya dapat mengantar orang dari Nunukan ke Sebatik maupun dari Sebatik ke Kota Tawau. Akses yang mudah tersebut mempermudah masyarakat memasarkan hasil-hasil pertanian, perkebunan dari dan ke Nunukan maupun dari dan ke Tawau. Faktor aksesibilitas merupakan salah satu faktor terjadinya perdagangan lintas negara. Walaupun itu dilakukan secara ilegal, karena belum adanya payung hukum yang mengatur perdagangan kedua negara.

\section{Faktor Biaya Dan Harga}

Rata-rata harga barang yang dibeli dari Kota Tawau relatif lebih murah jika dibandingkan dengan harga barang-barang yang dibeli dari Nunukan. Sedangkan hasil-hasil pertanian, perkebunan dan perikanan, para pembeli Malaysia berani membeli dengan harga yang lebih tinggi jika dibandingkan apabila hasil pertanian, perkebunan, dan perikanan dijual di Nunukan yang harganya relatif lebih murah. 


\section{Latar Belakang Budaya dan Hubungan Emosional}

Faktor geografis dan topografi antara Pulau Sebatik dengan Kota Tawau yang berdekatan menyebabkan banyak terjadi asimilasi kebudayaan dan hubungan emosional (kekeluargaan) di antara masyarakat kedua daerah tersebut. Percampuran bahasa, kehidupan sehari-hari, dan adanya perkawinan di antara mereka berdampak pada kedekatan secara budaya dan emosional di antara kedua daerah tersebut. Patut dicatat, hal ini sudah berlangsung sejak lama.

\section{POLA PERDAGANGAN LINTAS BATAS DI PULAU SEBATIK KABUPATEN NUNUKAN}

Pada dasarnya setiap individu memiliki kebutuhan dasar (basic needs) untuk melangsungkan hajat hidupnya. Setiap individu tidak mungkin dapat memenuhi kebutuhan-kebutuhan dasarnya tersebut sendirian tanpa bantuan individu lainnya. Demikian juga dalam konteks kelompok, mereka tetap memerlukan berinteraksi dengan kelompok lainnya dalam upaya memenuhi dan melangsungkan hajat hidupnya.

1. Dari Pola Direct Barter Hingga Direct Trading

Secara tradisional, perdagangan lintas batas antara penduduk Pulau Sebatik dengan penduduk Kota Tawau dilakukan dengan cara pertukaran barang (hasil hutan) atau yang disebut dengan barter. Aktifitas direct barter ini sudah berlangsung lama bahkan sebelum Indonesia merdeka.

Pola perdagangan yang berkembang pada tahun-tahun terakhir ini sudah tidak lagi dalam pola direct barter saja, melainkan sudah berkembang menjadi pola direct trading (jual-beli langsung). Masyarakat yang dulu membawa hasil perkebunan, pertanian dan hasil tangkapan ikan di laut untuk ditukar dengan bahan pokok, sekarang hasil perkebunan, pertanian dan hasil nelayan yang bernilai tinggi sengaja dijual ke Kota Tawau untuk memperoleh Ringgit (sebagai alat tukar) untuk membeli berbagai kebutuhan dan disimpan sebagai alat tukar berikutnya.

Namun tidak berarti pola barter sudah tidak dipakai lagi. Pada saat-saat dimana salah satu penduduk tidak memiliki cukup uang Ringgit untuk berbelanja kebutuhan sehari-hari ke Malaysia, maka hasil pertanian, perkebunan dan hasil tangkapan nelayan masih dapat digunakan sebagai alat tukar.

Dengan demikian pola perdagangan yang berkembang di wilayah perbatasan Pulau Sebatik Kabupaten Nunukan dengan wilayah Kota Tawau tidak lagi hanya sekedar saling bertukar barang-barang kebutuhan, namun sudah mengarah pada transaksi jual-beli yang lambat laun perkembangannya pasti mengarah pada kegiatan untuk mencari keuntungan yang lebih besar lagi.

2. Jenis-Jenis Dan Harga Komoditas yang diperdagangkan

Komoditas utama yang dimanfaatkan masyarakat untuk melakukan barter dengan penduduk di Kota Tawau adalah hasil-hasil pertanian, perkebunan dan hasil tangkapan ikan nelayan dan lain-lain. Dengan membawa hasil-hasil pertanian, perkebunan dan hasil tangkapan ikan nelayan sebaliknya, saat kembali ke Sebatik, mereka membawa berbagai barang kebutuhan sehari-hari seperti sabun, pasta gigi, gula, susu, minyak goreng, pakaian, dan berbagai barang lainnya. 
Sementara itu jenis barang-barang yang banyak diperdagangkan oleh penduduk Kota Tawau pada umumnya adalah bahan makanan dan khususnya yang merupakan bahan pokok seperti, minyak goreng, gula, kedelai, garam, kopi, bawang, telur, susu bubuk dan lain-lain.

Selain bahan-bahan makanan, penduduk di Pulau Sebatik juga membeli bahan-bahan kebutuhan untuk bangunan seperti semen, seng, asbes, paku, besi dan bahan bakar minyak (BBM) seperti bensin, minyak tanah, dan solar serta sesekali membeli juga barang-barang kelengkapan penting lainnya seperti mesin diesel, eletronik dan alat-alat telekomuniasi. Barang-barang tersebut terpaksa dibeli di Kota Tawau mengingat dari segi aksesibilitas lebih memungkinkan sehingga secara keseluruhan lebih efisien dibandingkan apabila mereka harus membeli dari Nunukan atau ke Tarakan.

Adapun untuk volume dan nilai barang yang diperdagangkan tidak dapat dilacak dengan pasti. Hal ini dikarenakan semua transaksi perdagangan di wilayah tersebut tidak terpantau ataupun tercatat secara resmi. Transaksi yang berlangsung sejak berpuluh bahkan beratus tahun lalu terjadi secara alamiah tanpa mengenal adanya batas yurisdiksi negara yang berbeda. Secara turun temurun masyarakat di perbatasan khususnya di pulau Sebatik sudah terbiasa saling berkomunikasi layaknya mereka satu bangsa. Hal ini terjadi karena jarak secara fisik geografis mereka berdekatan dibandingkan dengan masyarakat di daerah lainnya.

3. Lokasi Perdagangan Lintas Batas

Meskipun kegiatan yang berlangsung adalah perdagangan lintas batas yang melibatkan masyarakat di kedua negara, namun lokasi perdagangan lintas batas ini berlangsung lebih banyak di wilayah Kota Tawau. Secara geografis, sebagaimana telah diuraikan di bagian sebelumnya, masyarakat yang tinggal di desa-desa perbatasan Indonesia khususnya di Pulau Sebatik Kabupaten Nunukan lebih mudah memasarkan hasil-hasil pertanian, perkebunan dan hasil tangkapan ikan ke Kota Tawau jika dibandingkan ke Nunukan dan ditambah lagi dengan keuntungan harga yang lebih tinggi jika dijual di Kota Tawau. Sehingga kebiasaan melakukan pembelian barangbarang kebutuhan pokok sehari-hari dan kebutuhan sekundernya ke Kota Tawau masih tetap dipertahankan bahkan cenderung dalam volume dan intensitas yang semakin tinggi.

4. Fenomena Ketergantungan

Aktivitas perdagangan lintas batas ini apabila dikaji dari perspektif teori demand and supply ternyata dapat dikatakan berjalan secara kurang seimbang. Dengan kata lain masih nampak adanya indikasi ketergantungan yang sangat tinggi dari salah satu pihak yakni dari penduduk di Pulau Sebatik terhadap supply barang-barang kebutuhan pokok dari Kota Tawau.

Hal ini dapat dipahami mengingat kondisi wilayah di daerah perbatasan khususnya Pulau Sebatik Kabupaten Nunukan belum berkembang secara optimal sehingga masih sangat bergantung dengan Kota Tawau. Dengan pola perdagangan yang tidak seimbang dan cenderung monopolistik ini, dalam jangka panjang jelas merugikan masyarakat kita sebagai konsumen pasar Kota Tawau. 
Persoalan lain yang tidak kalah pentingnya untuk diperhatikan adalah semakin berkurangnya rasa nasionalisme masyarakat di daerah perbatasan sebagai akibat tak sampainya kemakmuran di wilayah perbatasan, sementara masyarakat merasa lebih "terlindungi" oleh keberadaan negara tetangga yang lebih dapat menjamin kelangsungan hidup mereka. Fenomena ketergantungan masyarakat terhadap pasokan barang-barang dari negara tetangga di berbagai wilayah perbatasan ternyata tidak hanya berhenti pada kebutuhan pemenuhan bahan pokok, melainkan sudah merembet pada kebutuhan akan barang-barang sekunder bahkan barang-barang mewah dan itu dapat diperoleh dari hasil perdagangan lintas batas.

Tingginya tingkat ketergantungan masyarakat di kedua Pulau Sebatik Kabupaten Nunukan ini disebabkan lemahnya posisi mereka terhadap pedagang dari Kota Tawau. Jika masyarakat di Pulau Sebatik sangat membutuhkan pasokan barang-barang kebutuhan pokok, sebaliknya warga Kota Tawau di perbatasan tersebut dalam posisi tidak terlalu membutuhkan barang-barang dari Indonesia.

\section{ANALISA SWOT PERDAGANGAN LINTAS BATAS DI PULAU SEBATIK KABUPATEN NUNUKAN}

Metode analisa SWOT selalu diawali dengan kajian keadaan secara internal terlebih dahulu baru kemudian dilanjutkan dengan kajian keadaan secara ekternal.

1. Kekuatan (Strengths)

a. Perkembangan pembangunan Kabupaten Nunukan dan Pulau Sebatik menunjukkan trend meningkat. Dalam beberapa tahun terakhir ini Kabupaten Nunukan (dan juga Pulau Sebatik) terus melakukan pembenahan-pembenahan di berbagai sektor. Kuantitas dan kualitas sarana-prasarana terus ditingkatkan, hal ini menjadi modal dan kekuatan utama dalam mendorong optimalisasi perdagangan lintas batas di Pulau Sebatik dengan Kota Tawau yang pada akhirnya berdampak pada meningkatnya tingkat kesejahteraan masyarakat di Pulau Sebatik.

b. Ketersediaan sumber daya alam yang melimpah di Pulau Sebatik juga merupakan modal dan kekuatan utama dalam perdagangan lintas batas. Seperti diketahui bahwa Pulau Sebatik merupakan penghasil padi adan, kelapa sawit, kakao, buahbuahan, dan tebu dalam jumlah yang cukup besar untuk dijadikan komoditi perdagangan lintas batas.

c. Niat dan kemauan dari Pemerintah Pusat dan Pemerintah Daerah yang sudah mulai memprioritaskan pembangunan di kawasan perbatasan (pembangunan kawasan perbatasan dari yang inward looking menjadi outward looking). ${ }^{7}$

7 Lihat lampiran UU Nomor 17 Tahun 2007 tentang Rencana Pembangunan Jangka Panjang Nasional (RPJPN) 2005-2025 bagian lampiran, antara lain Sub-bab II.1. (Kondisi Saat ini) Point H (Wilayah dan Tata Ruang) nomor 4, hlm. 19, Sub-bab II.2. (Tantangan) Point F (Pertahanan dan Keamanan) nomor 2, hlm, 30, Sub-bab IV.1.2. (Mewujudkan Bangsa yang Berdaya-saing) Point D (Sarana Prasarana yang Memadai dan Maju) nomor 30, hlm. 55, Sub-bab IV.1.5. (Mewujudkan Pembangunan yang Lebih Merata dan Berkeadilan) nomor 4, hlm. 66 dan Sub-bab IV.1.7. (Mewujudkan Indonesia menjadi Negara Kepulauan yang Mandiri, Maju, Kuat dan Berbasiskan Kepentingan Nasional) nomor 4, hlm. 75. 
d. Keinginan kuat untuk menjadikan Indonesia sebagai negara maritim yang besar dan tangguh menjadi modal utama dalam rangka pembangunan kawasan perbatasan NKRI.

2. Kelemahan (Weaknesses)

a. Walaupun perkembangan pembangunan di Pulau Sebatik menunjukkan trend yang meningkat, akan tetapi beberapa sarana dan prasarana yang khusus mendukung perdagangan lintas batas dianggap kurang memadai. Jumlah armada laut yang melayani transportasi dari dan ke Pulau Sebatik belum seimbang dengan intensitas perdagangan lintas batas. Selain itu, belum adanya terminal khusus bongkar muat barang yang memadai juga menjadi kelemahan yang perlu dibenahi agar tidak menghambat jalannya perdagangan lintas batas. Demikian juga dengan kondisi Pos Lintas Batas yang terkesan seadanya. Hal ini berbanding terbalik dengan situasi di Kota Tawau.

b. Keberadaan KK Sosek Malindo dirasa belum memberikan dampak yang signifikan terhadap perkembangan perdagangan lintas batas. Setelah berjalan dua setengah dekade terakhir, kerjasama sosek pada level pusat ini dirasakan banyak bermanfaat, terutama dalam kerjasama pembangunan sarana prasarana perbatasan. Namun hasil kerjasama dalam bidang sosial-ekonomi di tingkat daerah (Sosekda) dirasakan masih belum berhasil meningkatan kesejahteraan masyarakat perbatasan. Walaupun sesungguhnya telah pula dihasilkan berbagai kesepakatan kerjasama, tetapi yang terealisasi masih sedikit. Kecilnya realisasi diatas, telah dirasakan oleh kedua belah pihak (RI-Malaysia). Hasil pembahasan dan diskusi bersama, oleh kedua pihak di identifikasi ada 3 (tiga) kendala utama yang dihadapi dan perlu diatasi, meliputi aspek struktur, mekanisme pengambilan keputusan kerjasama di dalam General Border Committee (GBC), dan focus dan lingkup lokasi usulan kesepakatan. Persoalan struktur dan mekanisme mengakibatkan rentang waktu dan birokrasi pengambilan Sidang High Level Committee yang bersidang setahun sekali, harus menunggu persetujuan Sidang GBC yang bersidang pada tahun berikunya. Hal tersebut tentu saja akan memperlama dan memperpanjang proses dan mekanisme persetujuan hasil-hasil Sidang Sosekda. Untuk itu maka Struktur organisasi Kerjasama KK/JKK Sosek Malindo dalam kerangka GBC perlu disederhanakan agar rentang waktu/masa, birokasi dan mekanisme pengambilan keputusan, pengusulan dan persetujuan program kerjasama yang disepakati dapat diperpendek. Di samping persoalan struktur dan mekanisme dijelaskan di atas, kedua belah pihak juga menyadari bahwa bidang-bidang kerjasama yang disepakati dalam forum KK/JKK Sosek tingkat provinsi/negeri cenderung terlalu melebar dan melampau kewenangan tingkat provinsi/negeri. Bahkan sejumlah bidang kerjasama yang dibahas dan diusulkan daerah merupakan domain kerjasama bilateral yang menjadi kewenangan dari masing-masing Pemerintah Pusat. ${ }^{8}$ Selain itu diperlukan revisi

\footnotetext{
8 Lihat artikel "TOR Kerjasama Sosek Malindo Perlu Disempurnakan" yang ditulis oleh Fuad Asaddin dan dipublikasikan pada tanggal 20 Juni 2010 melalui website Biro Perbatasan, Penataan
} 
terhadap ketentuan-ketentuan perdagangan lintas batas sebagaimana tertuang dalam Persetujuan mengenai Perdagangan Lintas Batas antara Pemerintah Republik Indonesia dan Pemerintah Malaysia untuk disesuaikan dengan kondisi terkini.

c. Fenomena ketergantungan penduduk Pulau Sebatik terhadap Kota Tawau dan ketidakseimbangan intensitas perdagangan antara Pulau Sebatik dan Kota Tawau menjadi kelemahan tersendiri yang perlu mendapatkan perhatian. Hal ini adalah tentang bagaimana agar nilai tawar supply and demands dari penduduk Pulau Sebatik dengan komoditas dagangnya dapat ditingkatkan setara atau bahkan melebihi penduduk dan komoditas dagang Kota Tawau.

d. Kuantitas aparat pertahanan dan keamanan yang minim di Pulau Sebatik menjadi kelemahan dalam rangka menanggulangi perdagangan lintas batas yang illegal.

3. Kesempatan/Peluang (Opportunities)

a. Adanya pertukaran/transfer ilmu pengetahuan dan budaya di kalangan masyarakat Pulau Sebatik dengan masyarakat Kota Tawau baik secara langsung maupun tidak langsung dapat meningkatkan kompetensi dan kapabilitas masyarakat yang berdampak pada peningkatan kesejahteraan masyarakat kawasan perbatasan NKRI.

b. Hubungan baik antara Indonesia-Malaysia setidaknya dari sisi ekonomi/perdagangan dan keberadaan KK Sosek Malindo merupakan peluang yang harus dimaksimalkan demi terciptanya perdagangan lintas batas yang menguntungkan kedua belah pihak.

c. Adanya dan kemudahan aksesibilitas jalur laut dan darat yang menghubungkan Pulau Sebatik dan Kota Tawau, merupakan suatu kesempatan untuk menarik manfaat ekonomi antar negara.

d. Adanya pasar/market yang saling menguntungkan untuk menjual hasil produksi alam atau komoditas penduduk Pulau Sebatik ke Kota Tawau merupakan peluang yang harus dimaksimalkan. Selain itu, wilayah Sabah (Tawau) Malaysia, bukan saja merupakan pasar potensial bagi produk-produk Kalimantan Utara, akan tetapi juga sebagai pintu gerbang pemasaran ke negara lain seperti Taiwan, Singapura bahkan Timur Tengah. ${ }^{9}$

4. Ancaman (Threats)

a. Tidak terdeteksinya dengan jelas nilai-nilai transaksi perdagangan lintas batas berpotensi merugikan negara dalam jumlah besar. Hal ini berkaitan dengan pengenaan pajak ekspor impor.

b. Ancaman masuknya barang-barang illegal (selundupan) melalui perdagangan lintas batas dan juga perdagangan narkotika dan zat terlarang patut diwaspadai sebagai faktor yang dapat merusak tatanan dan stabilitas perdagangan lintas batas antara Pulau Sebatik dengan Kota Tawau.

Wilayah dan Kerjasama Sekretariat Daerah Provinsi Kalimantan Timur. Artikel diunduh pada hari Kamis 21 Juli 2011 jam 23.00 WITA.

${ }^{9}$ Lihat Pusat Kajian Administrasi Internasional, 2004, “Laporan Akhir Kajian Manajemen Wilayah Perbatasan Negara", Lembaga Administrasi Negara, Jakarta, hlm.50. 


\section{ISU UTAMA PERDAGANGAN LINTAS BATAS DI PULAU SEBATIK KABUPATEN NUNUKAN}

Memperhatikan Analisa SWOT terhadap perdagangan lintas batas antara Pulau Sebatik dengan Kota Tawau, maka isu-isu utama yang patut mendapatkan perhatian secara lebih serius agar perdagangan lintas batas dapat lebih optimal adalah:

1. Pembangunan dan pemenuhan sarana dan prasarana perdagangan di Pulau Sebatik

Kelengkapan sarana dan prasarana perdagangan lintas batas merupakan syarat utama dalam suatu sistem perdagangan. Tanpa sarana dan prasarana yang lengkap dan memadai bisa dipastikan perdagangan akan mengalami hambatan atau hasil yang diperoleh dari perdagangan tidak optimal. Sebagai contoh: saat ini di Pulau Sebatik belum memiliki terminal atau lokasi yang dikhususkan untuk bongkar muat barang, hal ini tentunya berpengaruh terhadap efisiensi dan efektifitas perdagangan lintas batas. Jika Memiliki lokasi khusus untuk bongkar muat barang, perdagangan lintas batas akan lebih optimal.

Contoh lain, akses dari Pulau Sebatik ke Kota Tawau atau sebaliknya sangat dekat dan relatif mudah dijangkau, tetapi armada laut yang melayani transporatsi tersebut sangat sedikit dan bisa dikatakan agak sedikit mahal. Bandingkan jika pemerintah daerah atau pusat dengan sengaja membangun terminal penyeberangan yang dilengkapi dengan kapal angkut barang ukuran besar yang memiliki rute dan jadwal yang teratur serta ongkos yang lebih murah, tentunya hal ini akan sangat menguntungkan para pedagang dari Pulau Sebatik, setidaknya bisa menghemat ongkos penyebarangan dan pengangkutan.

Masih banyak contoh lainnya sehubungan dengan minimnya sarana prasarana yang berimbas pada kurang optimalnya perdagangan lintas batas antara pedagang Pulau Sebatik dengan Kota Tawau. Tentu saja hal ini harus mendapatkan perhatian dari semua pihak yang terkait.

2. Kinerja KK Sosek Malindo

Untuk saat ini, selain Pemerintah Provinsi Kalimantan Utara dan Pemerintah Kabupaten Nunukan, KK Sosek Malindo merupakan lembaga yang memiliki peran dan tanggung jawab terhadap kelangsungan perdagangan lintas batas antara Pulau Sebatik dengan Kota Tawau. Ini adalah tentang bagaimana peran aktif dan realisasi dari program-program yang disusun oleh KK Sosek Malindo untuk mengoptimalkan perdagangan lintas batas tersebut. ${ }^{10}$

3. Persetujuan mengenai Perdagangan Lintas Batas antara Pemerintah Republik Indonesia dan Pemerintah Malaysia

Persetujuan mengenai Perdagangan Lintas Batas antara Pemerintah Republik Indonesia dan Pemerintah Malaysia adalah salah satu dasar hukum yang dipakai dalam implementasi perdagangan lintas batas antara Indonesia dengan Malaysia, termasuk di dalamnya perdagangan lintas batas antara Pulau Sebatik dengan Kota Tawau. Sejak disepakati pada tahun 1970, tentu saja diperlukan beberapa revisi atau penyesuaian dengan kondisi terkini, mengingat bidang perdagangan adalah bidang 
yang bergerak cepat mengkuti perkembangan jaman dan trend yang berlaku saat itu. Jangan sampai dikarenakan aturan hukum yang tidak mampu menyesuaikan diri menghambat optimalisasi perdagangan lintas batas.

4. Aspek pertahanan dan keamanan untuk mencegah dan menindak perdagangan lintas batas illegal yang berpotensi merugikan negara

Sebagaimana diketahui bahwa selama ini pendekatan yang dilakukan oleh Pemerintah Indonesia terhadap kawasan perbatasannya adalah pendekatan pertahanan-keamanan dan pendekatan kesejahteraan. Kerugian negara akibat penyelundupan barang-barang dari dan ke Tawau harus dicegah, demikian juga dengan perdagangan barang-barang illegal dan berbahaya seperti narkotika dan zat terlarang. Peran dari aparat pertahanan-keamanan perlu untuk lebih ditingkatkan.

5. Daya saing perdagangan antara pedagang dari Pulau Sebatik terhadap pedagang Kota Tawau.

Ketergantungan terhadap negara tetangga wajib untuk dikurangi, ini masalah prestise, ini masalah harga diri bangsa, ini masalah persaingan antar negara bertetangga, ini masalah citra bangsa Indonesia di mata dunia. Fenomena penduduk Pulau Sebatik yang sangat tergantung (secara ekonomi) dengan Kota Tawau perlu untuk direduksi. Daya saing penduduk/pedagang/barang dagangan perlu untuk ditingkatkan agar setara atau bahkan melebihi Kota Tawau. Isu strategis peningkatan daya saing ini berkaitan erat dengan isu strategis pembangunan sarana dan prasarana perdagangan lintas batas. Tanpa sarana dan prasarana yang memadai, mustahil daya saing perdagangan akan meningkat.

\section{STRATEGI OPTIMALISASI PERDAGANGAN LINTAS BATAS DI PULAU SEBATIK KABUPATEN NUNUKAN}

Memperhatikan hasil analisa SWOT dan isu-isu strategis terkait perdagangan lintas batas negara, maka perlu disusun strategi dan rencana operasional mengoptimalkan perdagangan lintas batas yang bertujuan untuk meningkatkan kesejahteraan masyarakat Pulau Sebatik Kabupaten Nunukan. Berikut strategi dan upaya yang dimaksud:

1. Strategi percepatan pembangunan sarana dan prasarana perdagangan lintas batas di

Pulau Sebatik Kabupaten Nunukan

Tidak perlu diperdebatkan panjang lebar, ketersediaan sarana dan prasarana perdagangan mutlak diperlukan untuk optimalisasi perdagangan lintas batas di Pulau Sebatik Kabupaten Nunukan. Ketersediaan sarana dan prasarana perdagangan akan memberikan manfaat dan keuntungan yang maksimal bagi pedagang/masyarakat Pulau Sebatik yang berujung pada meningkatnya kesejahteraan masyarakat Pulau Sebatik. Selain itu, ketersediaan sarana dan prasarana yang memadai berbanding lurus dengan peningkatan daya saing perdagangan antara pedagang dari Pulau Sebatik terhadap pedagang Kota Tawau.

Adapun rencana operasional untuk mengimplementasikan strategi tersebut adalah sebagai berikut:

a. Penyusunan perencanaan yang matang pembangunan sarana dan prasarana perdagangan di Pulau Sebatik. 
b. Membuka kesempatan investor dalam dan luar negeri untuk berinvestasi terkait dengan pembangunan sarana dan prasarana perdagangan di Pulau Sebatik.

c. Meningkatkan kualitas sumber daya manusia khususnya di bidang perdagangan Pulau Sebatik dengan cara pemberian pelatihan-pelatihan terkait manajemen perdagangan lintas batas negara. Peningkatan partisipasi masyarakat juga termasuk disini.

d. Pemberian kemudahan-kemudahan prosedural (dalam koridor yang diperbolehkan) pelayanan perdagangan lintas batas, termasuk pemberian subsidi finansial kepada pedagang-pedagang yang memiliki potensi besar.

e. Pemberian pelatihan tentang manajemen eksploitasi sumber daya alam yang berwawasan lingkungan agar ketersediaan sumber daya alam dapat bertahan untuk jangka waktu yang lama.

2. Strategi peningkatan kinerja KK Sosek Malindo Tingkat Daerah Kalimantan Utara

Seperti yang telah diungkap sebelumnya, KK Sosek Malindo Tingkat Daerah Kalimantan Utara memiliki peran dan tanggung jawab besar terhadap keberlangsungan perdagangan lintas batas antara Pulau Sebatik dengan Kota Tawau melalui programprogram yang telah disusun dan dijalankan. Dapat dikatakan, program-program yang sudah, sedang dan akan dijalankan oleh KK Sosek Malindo Tingkat Daerah Kalimantan Utara merupakan cerminan situasi dan kondisi perdagangan lintas batas saat ini.

Peningkatan kinerja KK Sosek Malindo Tingkat Daerah Kalimantan Utara dapat berdampak pada optimalnya perdagangan lintas batas yang tentu saja bermuara pada meningkatnya kesejahteraan masyarakat Pulau Sebatik Kabupaten Nunukan.

Adapun rencana operasional untuk mengimplementasikan strategi tersebut adalah sebagai berikut:

a. Mengkaji ulang struktur dan birokrasi kinerja KK Sosek Malindo Tingkat Daerah Kalimantan Utara agar lebih ramping dan lebih cepat tanggap untuk membuat kebijakan terkait dengan problematika seputar perdagangan lintas batas.

b. Memaksimalkan agenda-agenda pertemuan dengan kolega di pihak Malaysia. Setiap pertemuan seyogyanya diikuti dengan implementasi konkrit hasil pertemuan tersebut.

3. Strategi penyesuaian/revisi dasar hukum perdagangan lintas batas Indonesia-Malaysia

Persetujuan mengenai Perdagangan Lintas Batas antara Pemerintah Republik Indonesia dan Pemerintah Malaysia adalah dasar hukum bagi pelaksanaan perdagangan lintas batas antara pedagang/masyarakat Pulau Sebatik dengan Kota Tawau. Teori yang dapat diajukan adalah "hukum harus mampu beradaptasi dan mengarahkan sebuah kegiatan menuju kesejahteraan masyarakat". Kegiatan yang dimaksud disini adalah perdagangan lintas batas. Oleh karena itu, jangan sampai hukum dianggap sebagai penghambat karena ketidakmampuannya merespon situasi dan kondisi terkini. Pembaharuan hukum harus selalu dilakukan. Hukum harus bersifat dinamis.

Adapun rencana operasional untuk mengimplementasikan strategi tersebut adalah sebagai berikut:

a. Melakukan telaah akademis-empiris secara berkala terhadap situasi terkini perdagangan lintas batas antara Pulau Sebatik dan Kota Tawau. 
b. Segera melakukan revisi/perubahan jika terdapat hal-hal terbaru yang belum diatur atau aturannya sudah tidak dapat diberlakukan lagi.

4. Strategi peningkatan kuantitas dan kualitas aparat pertahanan dan keamanan di Pulau Sebatik Kabupaten Nunukan

Tanpa jaminan keamanan dan pertahanan yang pasti dan kuat, sulit untuk menciptakan perdagangan lintas batas yang optimal. Aparat pertahanan-keamanan yang kuat akan membuat para pedagang merasa aman dan nyaman dalam melaksanakan perdagangan tanpa khawatir akan mengalami kerugian disebabkan banyaknya barangbarang selundupan yang berpotensi menghancurkan harga pasar. Semakin banyak transaksi perdagangan yang legal tidak saja menguntungkan para pedagang tetapi juga memberikan keuntungan kepada negara melalui pengenaan pajak dan bea ekspor-impor.

Selain itu, untuk menjaga ketahanan nasional, aparat pertahanan-keamanan berfungsi untuk mencegah dan menindak perdagangan-perdagangan illegal (perdagangan narkotika dan zat terlarang) yang berpotensi merusak moral dan mental bangsa Indonesia.

Adapun rencana operasional untuk mengimplementasikan strategi tersebut adalah sebagai berikut:

a. Peningkatan kemampuan bertempur dan penguasaan medan bagi para personel TNI-POLRI.

b. Penambahan alutsista secara kuantitas maupun kualitas.

c. Peningkatan kerjasama operasi pengamanan bersama dengan aparat pertahanan-keamanan Malaysia.

d. Peningkatan pengetahuan dan wawasan aparat pertahanan-keamanan akan seluk beluk teori dan hukum perdagangan lintas batas negara.

e. Pembekalan bela negara yang tepat kepada segenap warga negara Indonesia.

\section{PENUTUP}

Pada akhirnya, komitmen yang kuat dan diikiti dengan sikap tindak yang konsisten dari masing-masing pemangku kepentingan di pusat dan daerah ditambah dengan keterlibatan aktif dari masyarakat Pulau Sebatik dalam rangka menjalankan berbagai strategi optimalisasi perdagangan lintas batas untuk peningkatan kesejahteraan menjadi kunci utama. 


\section{DAFTAR PUSTAKA}

Ida Bagus Wyasa Putra, Aspek-aspek Hukum Perdata Internasional dalam Transaksi Bisnis Internasional, Refika Aditama, Bandung. 2000.

Pusat Kajian Administrasi Internasional, 2004, “Laporan Akhir Kajian Manajemen Wilayah Perbatasan Negara", Lembaga Administrasi Negara, Jakarta.

Adri Patton, 2009, "Deskripsi Perdagangan Lintas Batas Antar Negara Indonesia dan Malaysia di Pulau Sebatik Kabupaten Nunukan", hasil penelitian yang disampaikan dalam Diklat PIM II di Surabaya.

Iwan Vanany, 2011, "Pengadopsian Teknologi RFID: Analisa SWOT" dalam Jurnal Manajemen Usahawan Indonesia Vol.40 No.3 Mei-Juni 2011. 